\title{
PATHOGENS OF POTATO (Solanum tuberosum L.) TUBER (Phytophtora infestans) OCCURRING IN TREATMENTS WITH FOLIAR FERTILIZATION
}

\author{
${ }^{1}$ Bożena Cwalina-Ambroziak, ${ }^{2}$ Bożena Bogucka \\ ${ }^{1}$ Department of Phytopathology and Entomology, University of Warmia and Mazury \\ Prawocheńskiego 17, 10-720 Olsztyn, Poland \\ e-mail: bambr@uwm.edu.pl \\ ${ }^{2}$ Department of Agrotechnology and Crop Production Management, University of Warmia and Mazury \\ Oczapowskiego 8, 10-719 Olsztyn
}

Received: 17.10.2012

\begin{abstract}
The paper presents the results of a three-year exact plot experiment (2008-2010) established in Bałcyny (NE Poland). Three potato cultivars were grown: medium-early 'Adam', medium-late 'Pasja Pomorska', and late 'Ślęza'. The experimental factors were foliar fertilizers applied alone or in combination (Basfoliar 12-4-6, ADOB Mn, Solubor DF) and two levels of soil mineral fertilization $\left(\mathrm{N}_{1} \mathrm{P}_{1} \mathrm{~K}_{1}-80 \mathrm{~kg} \mathrm{~N} \times \mathrm{ha}^{-1}, 80 \mathrm{~kg} \mathrm{P} \times\right.$ ha${ }^{1}, 120 \mathrm{~K} \times$ ha $^{-1} ; \mathrm{N}_{2} \mathrm{P}_{2} \mathrm{~K}_{2}-120 \mathrm{~kg} \mathrm{~N} \times \mathrm{ha}^{-1}, 144 \mathrm{~kg} \mathrm{P} \times \mathrm{ha}^{-1}, 156$ $\left.\mathrm{K} \times \mathrm{ha}^{-1}\right)$. The experimental materials comprised potato tubers. The symptoms of soft rot (Pectobacterium carotovorum subsp. carotovorum), late blight (Phytophthora infestans) and dry rot (Fusarium spp.) were evaluated in $5 \mathrm{~kg}$ potato samples, and were expressed as the percentage mass of infected tubers. The rates of common scab (Streptomyces scabies) and black scurf (Rhizoctonia solani) infection were estimated on 100 tubers collected randomly after harvest, according to a nine-point scale, and were presented as a percentage infection index. In the laboratory, fungi were isolated on PDA medium from potato tubers immediately after harvest and after five-month storage. The incidence of tuber diseases depended on potato cultivars affected. The severity of tuber diseases varied between treatments with two levels of NPK fertilization and foliar fertilization. The lowest number of Fusarium-infected tubers was obtained from treatments where three foliar fertilizers were applied in combination, which was confirmed by the lowest abundance of fungal isolates. More fungi were isolated from potato tubers after harvest than after storage, but pathogens were more frequently isolated from stored tubers. After harvest, the lowest number of pathogenic fungi was isolated from the tubers of cv. 'Adam' in the non-fertilized treatment, and after storage - from the tubers of the late cultivars in the treatment with three foliar fertilizers applied in combination.
\end{abstract}

Key words: potato, tubers, diseases, fungi, mineral fertilization

\section{INTRODUCTION}

Under conditions of macro- and micronutrient deficiencies in the soil or nutrient uptake problems, multi-component fertilizers applied to potato leaves can almost instantly cure nutritional deficiencies (B o li g ło w a , 2003). Foliar micronutrient fertilization affects the yield (Brar and $\mathrm{Nawdeep}-\mathrm{Kaur}$, 2003) and quality (K o z e r a et al. 2006) of potato tubers. Trehan et al. (1995) reported a potato yield increase due to the inhibitory effect of foliar fertilization on late blight. Foliar fertilizers determine potato resistance to pathogenic infections ( $\mathrm{Mi} 11 \mathrm{~s}$ et al. 2006; M a h m o u d , 2007), and influence the species composition of fungal communities colonizing potato tubers (K u rzaw ińs ka, 1997; C w a lin a - A m broziak, 2002). According to the latter authors, Alternaria alternata, Colletotrichum coccodes, Rhizoctonia solani and species of the genus Fusarium are the main causal agents of tuber diseases.

The objective of the present study was to estimate the severity of tuber diseases in three potato cultivars after harvest as affected by mineral soil fertilization and foliar fertilization. The structure of fungal communities colonizing tubers directly after harvest and after five-month storage was also determined.

\section{MATERIALS AND METHODS}

Cultivars, medium-early 'Adam', medium-late 'Pasja Pomorska', and late 'Ślęza', were grown in a three-year plot experiment established on grey-brown podsolic soil developed from light silty loam 
of complex 2, quality class IIIa; the experiment was carried out by the Department of Agrotechnology and Crop Production Management, University of Warmia and Mazury in Olsztyn, in Bałcyny in 2008. Cereal crops were grown as a forecrop. Certified seed potato tubers were planted in rows, $40 \mathrm{~cm}$ apart, at a row spacing of $62.5 \mathrm{~cm}$. Tillage treatments and agricultural measures (as recommended by the Institute of Soil Science and Plant Cultivation - National Research Institute, Puławy) as well as the methods of plant protection against agrophages (as recommended by the Institute of Plant Protection - National Research Institute, Poznań) were identical in all experimental plots. The experiment was carried out in a randomized split-plot design, in three replications.

The following experimental factors were considered:

I - levels of mineral fertilization:

$\mathrm{N}_{1} \mathrm{P}_{1} \mathrm{~K}_{1}\left(\mathrm{~N} 80 \mathrm{~kg} \times \mathrm{ha}^{-1} \mathrm{P} 80 \mathrm{~kg} \times \mathrm{ha}^{-1}\right.$

$\left.\mathrm{K} 120 \mathrm{~kg} \times \mathrm{ha}^{-1}\right)$;

$\mathrm{N}_{2} \mathrm{P}_{2} \mathrm{~K}_{2}\left(\mathrm{~N} 120 \mathrm{~kg} \times \mathrm{ha}^{-1} \mathrm{P} 144 \mathrm{~kg} \times \mathrm{ha}^{-1}\right.$

$\left.\mathrm{K} 156 \mathrm{~kg} \times \mathrm{ha}^{-1}\right)$;

II - foliar fertilization:

A (Basfoliar 12-4-6 - $81 \times$ ha $^{-1}$ ), B (ADOB $\left.\mathrm{Mn}-41 \times \mathrm{ha}^{-1}\right), \mathrm{C}\left(\right.$ Solubor DF $\left.-21 \times \mathrm{ha}^{-1}\right)$, D (ADOB Mn $-21 \times$ ha $^{-1}+$ Solubor DF $11 \times$ ha $^{-1}$ ), E (ADOB Mn - $21 \times$ ha $^{-1}+$ Basfoliar 12-4-6 - $41 \times$ ha $^{-1}$ ), F (Basfoliar 12-4-6 - $41 \times$ ha $^{-1}+$ Solubor DF - $11 \times$ ha $\left.^{-1}\right)$, G (Basfoliar 12-4-6 - $2.71 \times$ ha $^{-1}+$ ADOB $\mathrm{Mn}-1.31 \times \mathrm{ha}^{-1}+$ Solubor DF $-0.71 \times$ ha $\left.{ }^{1}\right), \mathrm{H}$ (control treatment, without foliar fertilization). Mineral fertilizers were applied broadcast, at the same rate in all plots. Foliar fertilizers were applied once, at the beginning of flowering (BBCH 61). The composition of foliar fertilizers ( $\%$ by weight) was as follows: Basfoliar 12-4-6: $\mathrm{N}-12, \mathrm{~K}-6, \mathrm{P}$ $4, \mathrm{Mg}-0.2, \mathrm{~B}-0.02, \mathrm{Mn}-0.01, \mathrm{Cu}-0.01$, $\mathrm{Fe}-0.01, \mathrm{Zn}-0.005, \mathrm{Mo}-0.005$, ADOB $\mathrm{Mn}: \mathrm{N}-6.5, \mathrm{Mg}-2, \mathrm{Mn}-10$, Solubor DF: B - 17.5.

The symptoms of soft rot, late blight and dry rot were evaluated in $5 \mathrm{~kg}$ potato samples. The results were expressed as the mass percentage of infected tubers. The rates of common scab and black scurf infection were estimated on 100 tubers collected randomly after harvest in 2009 and 2010 according to a nine-point scale (R o z t r o p o w i c z, 1999; 1 - no symptoms, 9 - most severe symptoms) and were presented as a percentage infection index. Laboratory samples consisted of 30 tubers collected randomly in three replications per treatment, directly after harvest (in 2008-2010) and after five-month storage at $5^{\circ} \mathrm{C}$. Blocks $(0.5 \times 0.5$ $\times 1.5 \mathrm{~cm}$ ) were cut from the tubers and they were disinfected with $50 \%$ ethanol and $1 \%$ sodium hypochlorite, washed with distilled water and placed on PDA medium. After seven days of incubation, fungal colonies were inoculated onto agar slants for later microscopic identification according to the relevant keys and monographs (Arx, 1970; E11is , 1971; D o m s ch et al. 1980). The results were processed statistically by ANOVA (STATISTICA ${ }^{\circledR} 8.0$ 2008), and the significance of differences between means was determined by Duncan's test $(\mathrm{p}=0.05)$.

Temperature distribution patterns (May - August) were similar in the investigated growing seasons. Mean monthly temperatures in July and August were higher than the long-term average. Precipitation varied and rainfall totals were more than a half higher in 2009 and 2010, compared with 2008 (Table 1).

Table 1

Weather conditions (Meteorological Station in Bałcyny).

\begin{tabular}{ccccc}
\hline Month & 2008 & 2009 & 2010 & $\begin{array}{c}\text { Mean for } \\
1961-1995\end{array}$ \\
\hline \multicolumn{5}{c}{ Temperature, ${ }^{\circ} \mathrm{C}$} \\
May & 12.3 & 12.2 & 12.0 & 12.4 \\
June & 16.6 & 14.7 & 15.7 & 15.7 \\
July & 18.3 & 18.9 & 20.8 & 15.3 \\
August & 17.8 & 18.5 & 19.3 & 17.9 \\
\hline Mean for & 16.3 & 16.1 & 17.0 & 15.3 \\
growing season & & & & \\
\hline & Rainfall, mm & & \\
\hline May & 48.4 & 89.6 & 105.5 & 56.7 \\
June & 27.8 & 133.1 & 73.7 & 68.3 \\
July & 47.0 & 82.2 & 87.8 & 81.3 \\
August & 103.1 & 25.7 & 99.3 & 78.1 \\
\hline $\begin{array}{c}\text { Total for } \\
\text { growing season } \\
\text { Monthly total }\end{array}$ & 226.3 & 330.6 & 366.3 & 284.4 \\
\hline & & & \\
\hline
\end{tabular}

\section{RESULTS AND DISCUSSION}

The severity of tuber diseases varied between treatments with foliar fertilization and two levels of mineral fertilization. The intensity of soft rot was low in the growing season of 2010, and the percentage of infected tubers was significantly higher in cv. 'Adam' than in the other two cultivars (Table 2). Soft rot symptoms were not observed in 2009. There was no correlation between soft rot severity and the application of soil and foliar fertilizers. According to B a in et al. (1996), the optimum rates of calcium and magnesium fertilizers may reduce plant infection by Pectobacterium 
carotovorum subsp. atroseptica during the growing season, thus decreasing the incidence of soft rot on stored tubers. Mills et al. (2006) reported that potassium sorbate, potassium alum and copper sulfate exerted an inhibitory effect on bacterial pathogens under in vitro conditions.

In the present study, more tubers were infected by Phytophthora infestans and Fusarium spp. than by $P$. carotovorum subsp. carotovorum. Weather conditions during the growing season of 2010 supported the development of late blight and soft rot, compared with 2009. The highest percentage of tubers infected by $P$. infestans (means of cultivars) was noted in the Basfoliar 12-4-8 treatment, and the difference was statistically significant relative to the remaining treatments (Table 3). Weak symptoms of late blight infection were observed in 2009, and the pathogen did not attack the tubers of cv. 'Ślęza'. Stronger symptoms of late blight were noted on the tubers of cv. 'Adam' and 'Pasja Pomorska' grown in the plots with a higher level of NPK fertilization, compared with those from the plots with a lower level of mineral fertilization. As demonstrated by B a s u et al. (2003), potato plant spraying with zinc sulfate and copper sulfate reduced the severity of late blight. Rę barz and B orów - $\mathrm{c} \mathrm{z} \mathrm{a} \mathrm{k}$ (2007) reported that nitrogen applied at $180 \mathrm{~kg}$ $\mathrm{x} \mathrm{ha} \mathrm{a}^{-1}$ caused a significant decrease in the percentage share of tubers infected by $P$. infestans. Foliar application of phosphorus has been shown to reduce the incidence of infection with $P$. infestans $(\mathrm{C}$ o o k e and Litt le, 2002) and P. erythroseptica (Joh n s on et al. 2004).

In contrast to soft rot and late blight, more potato tubers showing symptoms of dry rot, in particular of cv. 'Ślęza', were obtained in 2009 (Table 4). The percentage of infected tubers of cv. 'Ślęza' was significantly higher, in comparison with the other two cultivars, and it was the highest in the Basfoliar 12-4-6 and ADOB Mn treatments. In the growing season of 2009, the severity of dry rot was higher in cv. 'Adam' in treatments with foliar fertilizers applied alone, compared with the other treatments. An analysis of the mean infection rates in cultivars and treatments revealed that the incidence of late blight and dry rot was higher in treatments with foliar fertilizers applied alone and with a higher level of mineral fertilization. The intensity of soft rot varied between fertilization treatments (Fig. 1). According to $\mathrm{Me} \mathrm{c} \mathrm{t} \mathrm{a} \mathrm{u} \mathrm{et} \mathrm{al.} \mathrm{(2002),} \mathrm{sodium} \mathrm{carbona-}$ te and aluminum chloride can inhibit the development of dry rot on potato tubers.

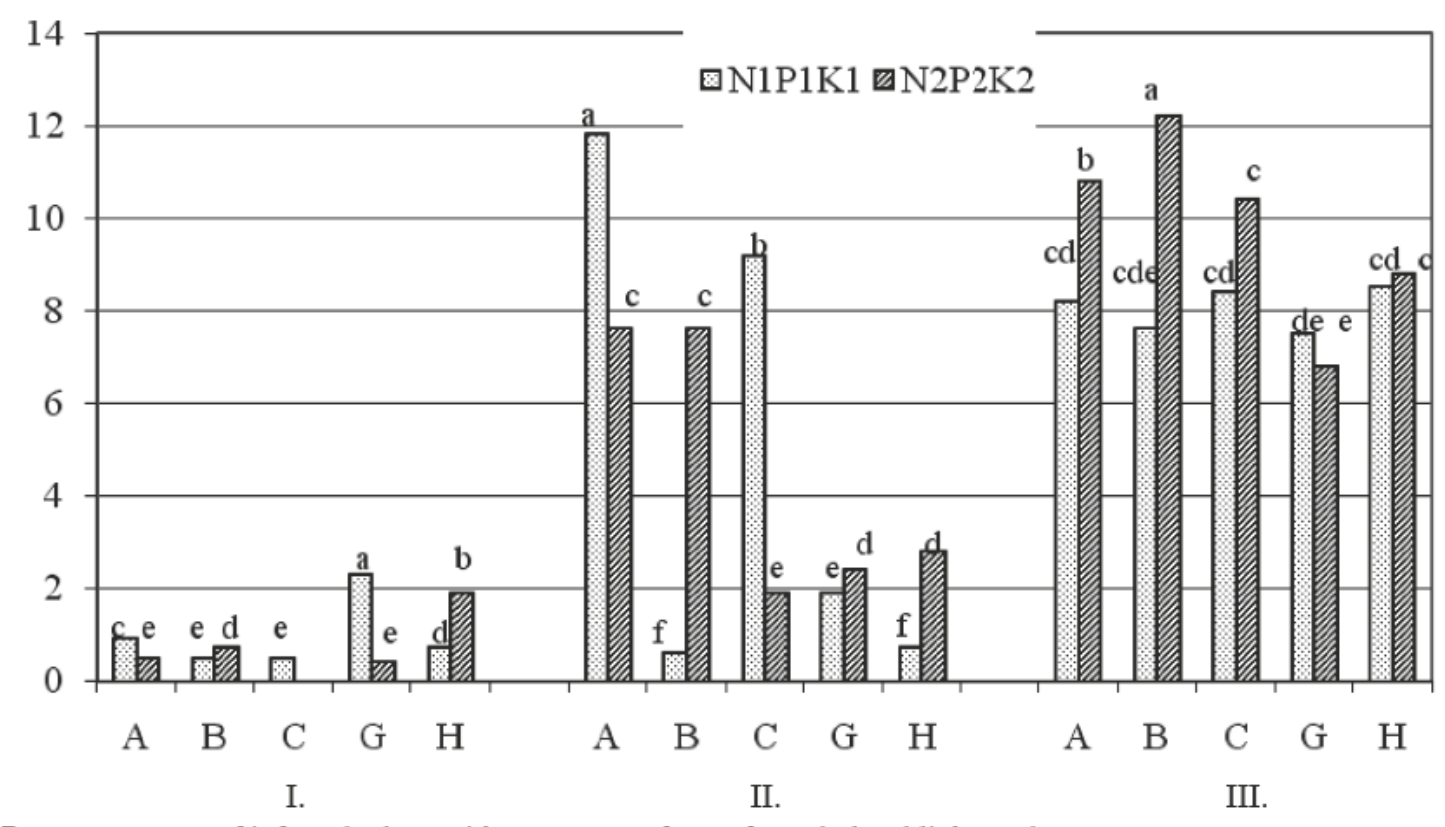

Fig. 1. Percentage mass of infected tubers with symptoms of: a. soft rot, b. late blight, c. dry rot

a, b, c, g, h - foliar fertilization (a-Basfoliar 12-4-6, b-ADOB Mn, c-Solubor or DF, g-Basfoliar 12-4-6 + ADOB Mn + Solubor DF, h-control), A,B - levels of mineral fertilization (A-N $80 \mathrm{~kg} \times \mathrm{ha}^{-1} \mathrm{P} 80 \mathrm{~kg} \times \mathrm{ha}^{-1} \mathrm{~K} 120 \mathrm{~kg} \times \mathrm{ha}^{-1}, \mathrm{~B}-\mathrm{N} 120 \mathrm{~kg}$ $\times$ ha $^{-1}$ P $144 \mathrm{~kg} \times$ ha-1 K $156 \mathrm{~kg} \times \mathrm{ha}^{-1}$

The highest severity of common scab infection was noted on the tubers of the late cultivars in 2009 and on the tubers of the medium-early cultivar in 2010 (Table 5). Significantly higher infection rates were found in non-foliar fertilized plants (lower level of mi- neral fertilization), as indicated by the average values of the infection index (Fig. 2). J a błoński (2003) demonstrated that $\mathrm{ADOB} \mathrm{Mn}$ and Basfoliar $36 \mathrm{E}$ had no influence on the severity of common scab infection. In the present study, significant differences occurred in 
the values of the infection index between the studied cultivars in both years, and stronger disease symptoms were observed in the treatment with a lower mineral fertilization level, except for cv. 'Adam' in 2010. K li $\mathrm{k} \mathrm{o} \mathrm{c} \mathrm{k} \mathrm{a} \mathrm{et} \mathrm{al.} \mathrm{(2005)} \mathrm{reported} \mathrm{that} \mathrm{sulfur} \mathrm{fertilization} \mathrm{at}$ $500 \mathrm{~kg} \mathrm{x} \mathrm{ha-1}$ provided effective control of Streptomyces scabies and Rhizoctonia solani. $\mathrm{R} \mathrm{e} \mathrm{p} \mathrm{s} \mathrm{i} \mathrm{e} \mathrm{n} \mathrm{e} \mathrm{and} \mathrm{Mi}$ n e i k i e ne (2006) observed no differences in severity of common scab on NPK fertilized and non-fertilized potato tubers, but found that mineral fertilization reduced the incidence of black scurf, which corroborates the findings of other authors ( $\mathrm{M} \mathrm{a} \mathrm{m} \mathrm{ta}$ and $\mathrm{Ku} \mathrm{m}$ a r, 2005; $\mathrm{P} \mathrm{u}$ a and $\mathrm{A} \mathrm{bza}, 2005$ ).

Over the entire experimental period, the tubers of medium-early cv. 'Adam' were the most infected by
$R$. solani, and the difference was statistically significant relative to the remaining cultivars. There was no correlation between the infection rates of black scurf and the type of foliar fertilizer (Table 6). However, the highest disease severity was noted in the treatment without foliar fertilization (higher level of NPK fertilization), as indicated by the average values of the infection index (Fig. 2). Rę b a r z and B orów c z a k (2007) observed the weakest symptoms of black scurf following the foliar application of Mikrosol U. The result of laboratory studies show that potassium added to PDA medium inhibited mycelial growth and the germination of $R$. solani sclerotia ( $\mathrm{Rit} \mathrm{ch}$ i e et al. 2006) as well as the growth and germination of $A$. solani spores $(\mathrm{B} 1$ a chiński et al. 1997; Feng and Zheng, 2006).

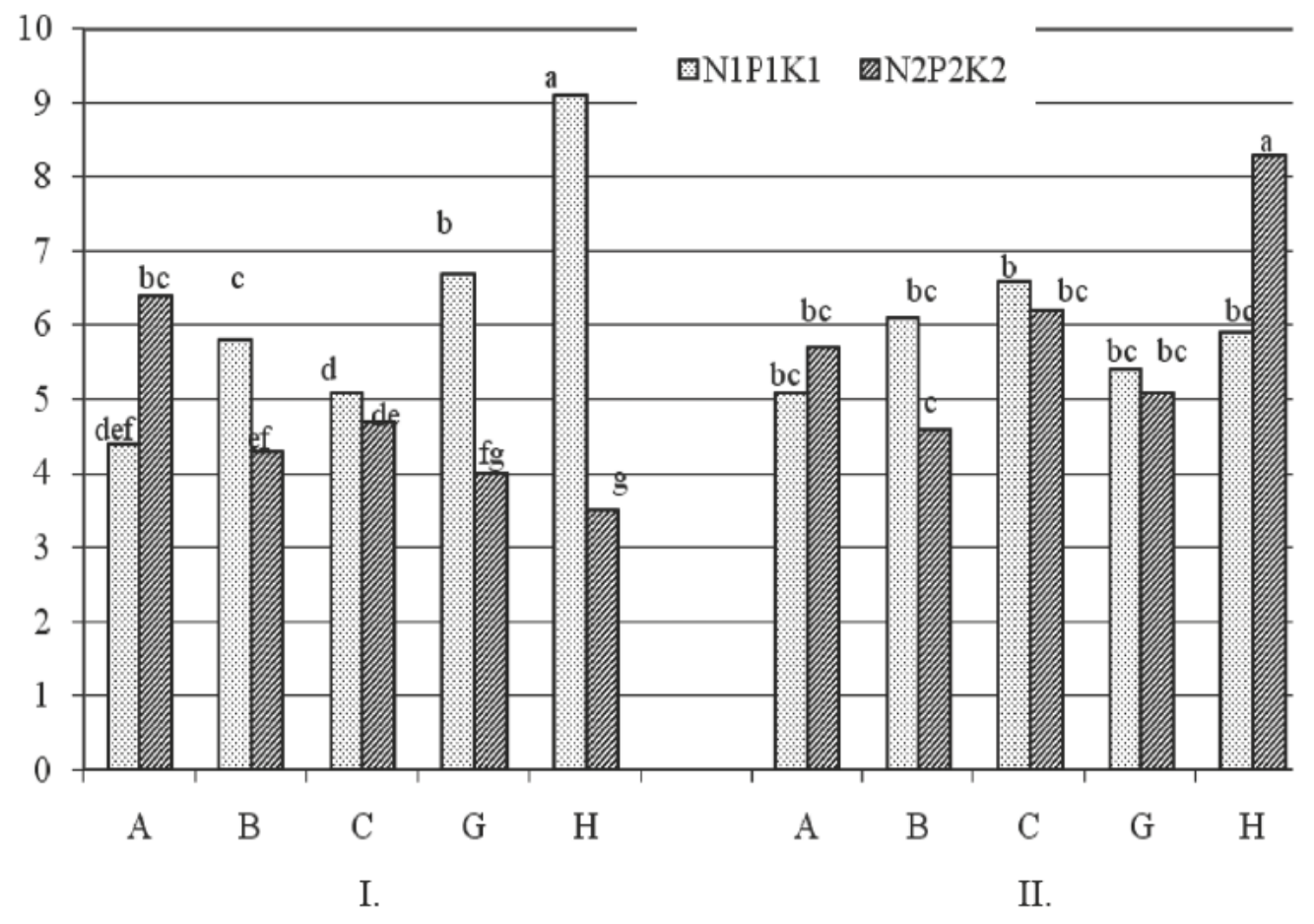

Fig. 2. Intensity (Ii in \%) a. of common scab, b. of rhizoctoniosis.

Explanations as in Fig 1.

Fungi isolated from the tubers of the analyzed potato cultivars (a total of 5969 isolates) were represented by 51 species of filamentous fungi as well as by non-sporulating cultures and yeast-like fungi. More fungal isolates (by 5.4\%) were obtained after harvest than after five-month storage, but more pathogenic fungi were isolated from stored tubers, including Colletotrichum coccodes which accounted for approximately $30 \%$ of all isolates (Fig. 3 I). According to Andrivon et al. (1999b), C. coccodes is the predominant fungal species colonizing potato tubers. A. alternata and $R$. solani had a similar share in the fungal community at both sampling times. In 2008 weather conditions (a warm summer with below-average rainfall) promoted the development of the early blight and anthracnose causal agents and suppressed the development of the causal agent of black scurf (Fig. 3 II). Species of the genus Fusarium ( $F$. avenaceum, $F$. concolor, $F$. culmorum, $F$. fusarioides, $F$. nivale, $F$. oxysporum, $F$. poae, $F$. solani) were isolated in insignificantly greater abundance from newly-harvested tubers, and the largest numbers of isolates were obtained in 2009. According to Esfah ani (2006), Loiveke (2006) and Peters et al. (2008), the main causal agents of dry rot are $F$. culmorum, $F$. oxysporum, $F$. solani, $F$. sambucinum and $F$. sulphureum. 




I.

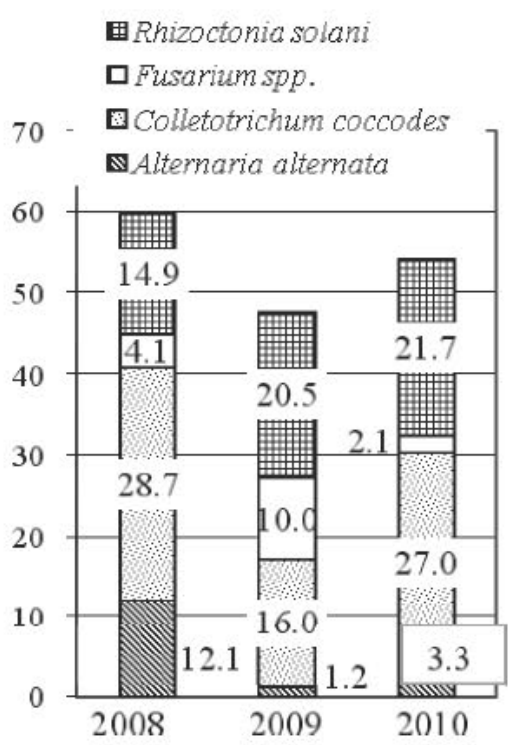

II.

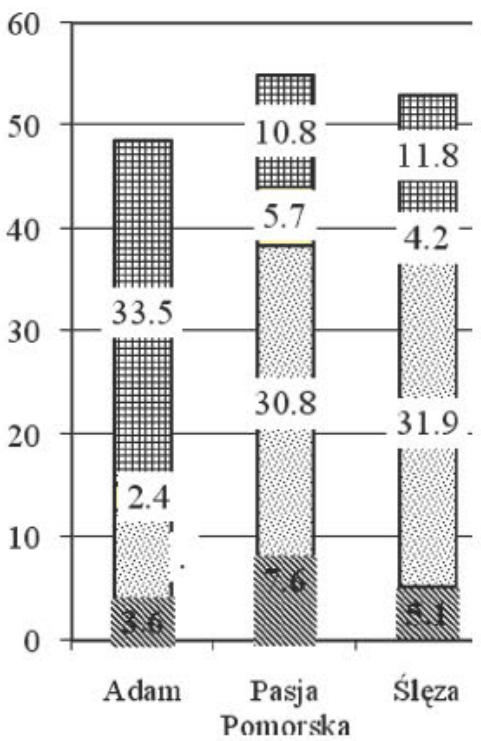

III.

IV

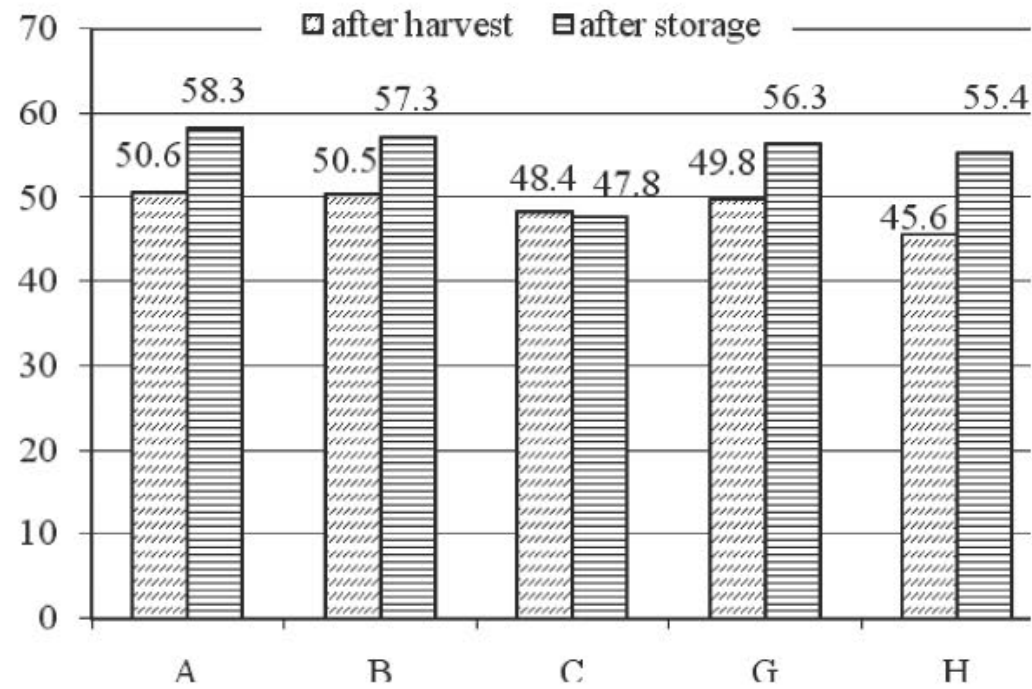

هafter harvest $\square$ after storage

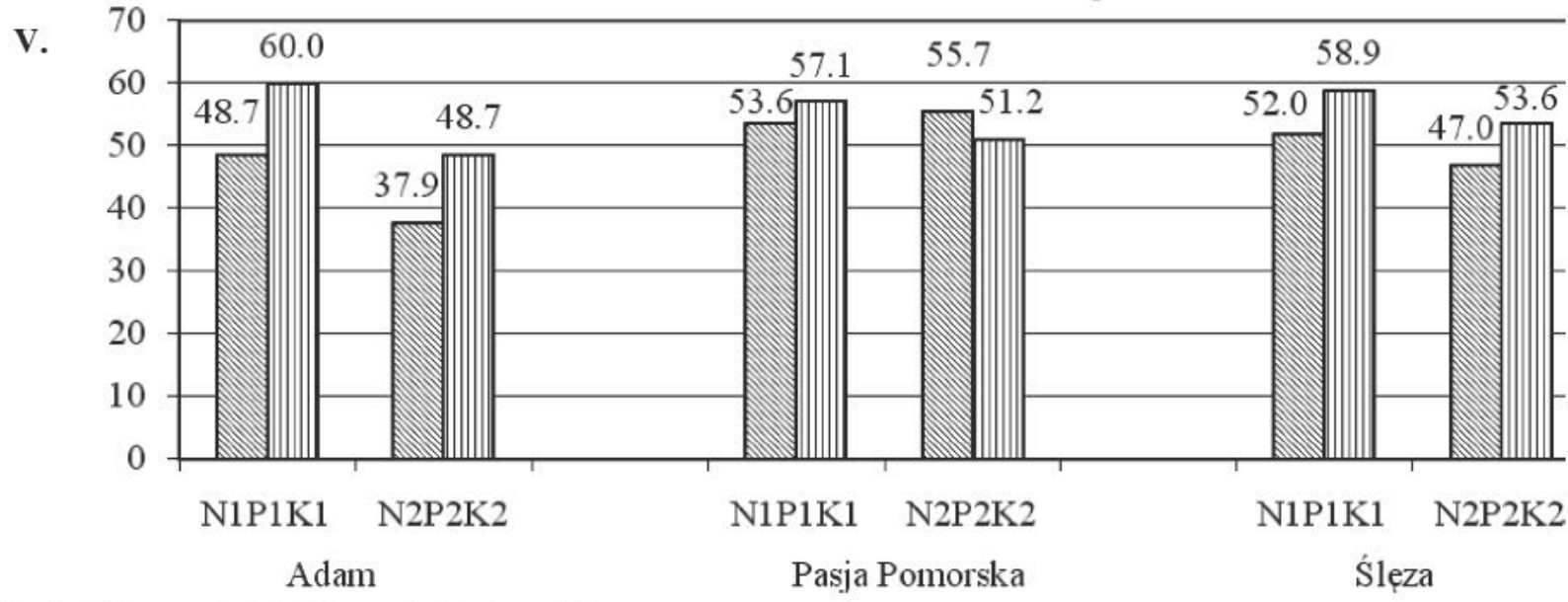

Fig. 3. Pathogens isolated from potato tubers (\%) Explanations as in Fig. 1. 
The remaining pathogens (A. solani, Botrytis cinerea, Helminthosporium solani) were isolated sporadically. More abundant communities of pathogenic fungi were isolated from the tubers of the late cultivars, compared with the medium-early cultivar (Fig. 3 III). The tubers of cv. 'Adam' were most abundantly colonized by $R$. solani, probably due to moderate temperatures in May and June, close to the long-term average, and high rainfall totals. In a study by Lutomirska and Szutkowska (2005), potato tuber infection by the above mentioned pathogen was more severe in irrigated plantations. In our experiment, the pathogens had the lowest share of the fungal community colonizing potato tubers after harvest in the treatment without foliar fertilization. The pathogens had an over $55 \%$ share of the fungal community colonizing potato tubers after storage in all treatments excluding that with Solubor DF (Fig. 3 IV). At both sampling times, pathogenic fungi were isolated more frequently from the treatment with a higher level of mineral fertilization, compared with the lower level, except for stored tubers of cv. 'Pasja Pomorska' (Fig. 3 V). C. coccodes, one of the most common potato pathogens, usually infects tubers of potato plants grown in nitrogen-deficient soils $(\mathrm{Celetti}$ et al. 1990).

Table 2

Percentage mass of tubers infected by Pectobacterium carotovorum subsp. carotovorum

\begin{tabular}{|c|c|c|c|c|c|c|c|c|c|c|c|c|c|c|}
\hline \multirow{3}{*}{ Cultivar } & \multirow{3}{*}{ NPK } & \multicolumn{6}{|c|}{2009} & \multicolumn{6}{|c|}{2010} & \multirow{3}{*}{$\mathrm{X}$} \\
\hline & & \multicolumn{5}{|c|}{ Foliar fertilization } & & \multicolumn{5}{|c|}{ Foliar fertilization } & \multirow{2}{*}{$\mathrm{x}$} & \\
\hline & & $\mathrm{A}^{* *}$ & $\mathrm{~B}$ & $\mathrm{C}$ & $\mathrm{G}$ & $\mathrm{H}$ & & $\mathrm{A}$ & $\mathrm{B}$ & $\mathrm{C}$ & G & $\mathrm{H}$ & & \\
\hline \multirow{2}{*}{ Adam } & $\mathrm{N}_{1} \mathrm{P}_{1} \mathrm{~K}_{1}{ }^{*}$ & $0 \mathrm{k}^{* * *}$ & $0 \mathrm{k}$ & $0 \mathrm{k}$ & $0 \mathrm{k}$ & 0k & Of & $1.6 \mathrm{j}$ & 0k & 0k & $8.6 \mathrm{a}$ & $2.2 \mathrm{i}$ & $2.5 \mathrm{~b}$ & $1.2 \mathrm{~b}$ \\
\hline & $\mathrm{N}_{2} \mathrm{P}_{2} \mathrm{~K}_{2}$ & 0k & Ok & 0k & 0k & $0 \mathrm{k}$ & Of & $2.7 \mathrm{gh}$ & $0 \mathrm{k}$ & 0k & $2.6 \mathrm{~h}$ & $8.2 b$ & $2.7 \mathrm{a}$ & $1.4 \mathrm{a}$ \\
\hline $\mathrm{x}$ & & Oh & Oh & $\mathrm{Oh}$ & $\mathrm{Oh}$ & Oh & Od & $2.2 \mathrm{~d}$ & Oh & $0 \mathrm{~h}$ & $5.6 \mathrm{a}$ & $5.2 \mathrm{~b}$ & $2.6 \mathrm{a}$ & $1.3 \mathrm{a}$ \\
\hline \multirow{2}{*}{ Pasja Pomorska } & $\mathrm{N}_{1} \mathrm{P}_{1} \mathrm{~K}_{1}$ & $0 \mathrm{k}$ & $0 \mathrm{k}$ & 0k & $0 \mathrm{k}$ & $0 \mathrm{k}$ & Of & $3.8 \mathrm{e}$ & $0 \mathrm{k}$ & $2.9 \mathrm{fg}$ & $5.2 \mathrm{c}$ & $0 \mathrm{k}$ & $2.4 \mathrm{c}$ & $1.2 \mathrm{~b}$ \\
\hline & $\mathrm{N}_{2} \mathrm{P}_{2} \mathrm{~K}_{2}$ & $0 \mathrm{k}$ & $0 \mathrm{k}$ & $0 \mathrm{k}$ & $0 \mathrm{k}$ & $0 \mathrm{k}$ & Of & $0 \mathrm{k}$ & $4.2 \mathrm{~d}$ & $0 \mathrm{k}$ & $0 \mathrm{k}$ & $3.0 \mathrm{f}$ & $1.4 \mathrm{~d}$ & $0.7 \mathrm{c}$ \\
\hline $\mathrm{x}$ & & Oh & Oh & $\mathrm{Oh}$ & Oh & Oh & Od & $1.9 \mathrm{e}$ & $2.1 \mathrm{~d}$ & $1.5 \mathrm{f}$ & $2.6 \mathrm{c}$ & $1.5 \mathrm{f}$ & $1.9 \mathrm{~b}$ & $1.0 \mathrm{~b}$ \\
\hline \multirow{2}{*}{ Ślęza } & $\mathrm{N}_{1} \mathrm{P}_{1} \mathrm{~K}_{1}$ & 0k & $0 \mathrm{k}$ & $0 \mathrm{k}$ & $0 \mathrm{k}$ & $0 \mathrm{k}$ & of & $0 \mathrm{k}$ & $2.7 \mathrm{gh}$ & 0k & 0k & $2.2 \mathrm{i}$ & $1.0 \mathrm{e}$ & $0.5 \mathrm{~d}$ \\
\hline & $\mathrm{N}_{2} \mathrm{P}_{2} \mathrm{~K}_{2}$ & $0 \mathrm{k}$ & $0 \mathrm{k}$ & 0k & $0 \mathrm{k}$ & $0 \mathrm{k}$ & Of & 0k & $0 \mathrm{k}$ & $0 \mathrm{k}$ & $0 \mathrm{k}$ & $0 \mathrm{k}$ & Of & $0 \mathrm{e}$ \\
\hline $\mathrm{x}$ & & $0 \mathrm{~h}$ & $\mathrm{Oh}$ & $0 \mathrm{~h}$ & $0 \mathrm{~h}$ & $\mathrm{Oh}$ & $0 \mathrm{~d}$ & $0 \mathrm{~h}$ & $1.4 \mathrm{f}$ & $0 \mathrm{~h}$ & $0 \mathrm{~h}$ & $1.1 \mathrm{~g}$ & $0.5 \mathrm{c}$ & $0.2 \mathrm{c}$ \\
\hline
\end{tabular}

Table 3

Percentage mass of tubers infected by Phytophthora infestans

\begin{tabular}{|c|c|c|c|c|c|c|c|c|c|c|c|c|c|c|}
\hline \multirow{3}{*}{ Cultivar } & \multirow{3}{*}{ NPK } & \multicolumn{6}{|c|}{2009} & \multicolumn{6}{|c|}{2010} & \multirow{3}{*}{$\mathrm{X}$} \\
\hline & & \multicolumn{5}{|c|}{ Foliar fertilization } & & \multicolumn{5}{|c|}{ Foliar fertilization } & \multirow{2}{*}{$\mathrm{x}$} & \\
\hline & & A & B & $\mathrm{C}$ & G & $\mathrm{H}$ & & A & B & $\mathrm{C}$ & G & $\mathrm{H}$ & & \\
\hline \multirow{2}{*}{ Adam } & $\mathrm{N}_{1} \mathrm{P}_{1} \mathrm{~K}_{1}$ & Oh & 0.8 no & $\mathrm{Oh}$ & Oh & Oh & $0.2 \mathrm{~h}$ & $13.0 \mathrm{e}$ & $\mathrm{Oh}$ & Oh & $1.61 \mathrm{mn}$ & $2.0 \mathrm{k}-\mathrm{n}$ & $3.3 \mathrm{f}$ & $1.7 \mathrm{e}$ \\
\hline & $\mathrm{N}_{2} \mathrm{P}_{2} \mathrm{~K}_{2}$ & $\mathrm{Oh}$ & $1.61 \mathrm{mn}$ & $\mathrm{Oh}$ & $\mathrm{Oh}$ & $\mathrm{Oh}$ & $0.3 \mathrm{gh}$ & $3.8 \mathrm{j}$ & 10.6 & 3.0 & 2.4 & $8.0 \mathrm{~g}$ & $5.6 \mathrm{e}$ & $2.9 \mathrm{~d}$ \\
\hline $\mathrm{x}$ & & 01 & $1.2 \mathrm{k}$ & 01 & 01 & 01 & $0.2 \mathrm{de}$ & $8.4 \mathrm{e}$ & $5.3 \mathrm{~g}$ & $1.5 \mathrm{jk}$ & $2.0 \mathrm{ij}$ & $5.0 \mathrm{~g}$ & $4.4 \mathrm{c}$ & $2.3 \mathrm{c}$ \\
\hline \multirow{2}{*}{ Pasja Pomorska } & $\mathrm{N}_{1} \mathrm{P}_{1} \mathrm{~K}_{1}$ & 2.0 & $\mathrm{Oh}$ & $\mathrm{Oh}$ & $\mathrm{Oh}$ & Oh & $0.4 \mathrm{gh}$ & $18.0 \mathrm{c}$ & 0 & 17.0 & $\mathrm{Oh}$ & Oh & $7.0 \mathrm{~d}$ & $3.7 \mathrm{c}$ \\
\hline & $\mathrm{N}_{2} \mathrm{P}_{2} \mathrm{~K}_{2}$ & Oh & $0 \mathrm{~h}$ & 1,4 & 2.0 & Oh & $0.7 \mathrm{~g}$ & $18.0 \mathrm{c}$ & 16.2 & 4.0 & 5.2 & 5.0hi & $9.7 \mathrm{c}$ & $5.2 \mathrm{~b}$ \\
\hline $\mathrm{x}$ & & $1.0 \mathrm{k}$ & 01 & $0.7 \mathrm{kl}$ & $1.0 \mathrm{k}$ & 01 & $0.5 \mathrm{~d}$ & $18.0 \mathrm{c}$ & $8.1 \mathrm{ef}$ & $10.5 \mathrm{~d}$ & 2.6hi & $2.5 \mathrm{hi}$ & $8.3 b$ & $4.4 \mathrm{~b}$ \\
\hline \multirow{2}{*}{ Ślęza } & $\mathrm{N}_{1} \mathrm{P}_{1} \mathrm{~K}_{1}$ & Oh & Oh & $\mathrm{Oh}$ & $\mathrm{Oh}$ & Oh & Oh & $38.0 \mathrm{a}$ & 2.8 & 38.0 & 10.0 & $2.2 \mathrm{klm}$ & $18.2 \mathrm{a}$ & $9.1 \mathrm{a}$ \\
\hline & $\mathrm{N}_{2} \mathrm{P}_{2} \mathrm{~K}_{2}$ & $0 \mathrm{~h}$ & Oh & $\mathrm{Oh}$ & $\mathrm{Oh}$ & $\mathrm{Oh}$ & $\mathrm{Oh}$ & $23.6 \mathrm{~b}$ & $17.0 \mathrm{~cd}$ & $3.1 \mathrm{jk}$ & 5.0hi & $3.7 \mathrm{j}$ & $10.5 b$ & $5.2 \mathrm{~b}$ \\
\hline $\mathrm{x}$ & & 01 & 01 & 01 & 01 & 01 & $0 \mathrm{e}$ & $30.8 \mathrm{a}$ & $9.9 \mathrm{~d}$ & $20.6 b$ & $7.5 \mathrm{f}$ & $3.0 \mathrm{~h}$ & $14.3 \mathrm{a}$ & $7.2 \mathrm{a}$ \\
\hline
\end{tabular}

Explanations as in Table 2 
Table 4

Percentage mass of tubers infected by Fusarium spp.

\begin{tabular}{|c|c|c|c|c|c|c|c|c|c|c|c|c|c|c|}
\hline \multirow{3}{*}{ Cultivar } & \multirow{3}{*}{ NPK } & \multicolumn{6}{|c|}{2009} & \multicolumn{6}{|c|}{2010} & \multirow{3}{*}{$X$} \\
\hline & & \multicolumn{5}{|c|}{ Foliar fertilization } & & \multicolumn{5}{|c|}{ Foliar fertilization } & \multirow{2}{*}{$\mathrm{X}$} & \\
\hline & & A & $\mathrm{B}$ & $\mathrm{C}$ & $\mathrm{G}$ & $\mathrm{H}$ & & A & B & $\mathrm{C}$ & $\mathrm{G}$ & $\mathrm{H}$ & & \\
\hline \multirow{2}{*}{ Adam } & $\mathrm{N}_{1} \mathrm{P}_{1} \mathrm{~K}_{1}$ & $4.0 n-r$ & $3.40-\mathrm{s}$ & $7.0 \mathrm{i}-\mathrm{m}$ & $4.41-r$ & $1.6 \mathrm{rt}$ & $4.1 \mathrm{e}$ & $0 \mathrm{t}$ & 10.0hij & $3.6 n-r$ & $6.8 \mathrm{i}-\mathrm{n}$ & $7.4 \mathrm{i}-1$ & $5.6 \mathrm{~d}$ & $4.8 \mathrm{~d}$ \\
\hline & $\mathrm{N}_{2} \mathrm{P}_{2} \mathrm{~K}_{2}$ & 10.0hij & 10.0hij & $16.0 \mathrm{fg}$ & $7.0 \mathrm{i}-\mathrm{m}$ & $6.0 \mathrm{k}-\mathrm{p}$ & $9.8 \mathrm{c}$ & $3.0 \mathrm{p}-\mathrm{t}$ & $7.0 \mathrm{i}-\mathrm{m}$ & $2.4 \mathrm{q}-\mathrm{t}$ & $0 \mathrm{t}$ & $0 \mathrm{t}$ & $2.5 \mathrm{f}$ & $6.1 \mathrm{c}$ \\
\hline $\mathrm{x}$ & & $7.0 \mathrm{gh}$ & $6.7 \mathrm{gh}$ & $11.5 \mathrm{e}$ & 5.7hi & $3.8 \mathrm{i}-\mathrm{m}$ & $7.0 \mathrm{c}$ & $1.5 \mathrm{mno}$ & $8.5 \mathrm{fg}$ & $3.0 \mathrm{kn}$ & $3.4 \mathrm{j}-\mathrm{n}$ & 3.7i-m & $4.0 \mathrm{~d}$ & $5.5 b$ \\
\hline \multirow{2}{*}{ Pasja Pomorska } & $\mathrm{N}_{1} \mathrm{P}_{1} \mathrm{~K}_{1}$ & $9.0 \mathrm{~h}-\mathrm{k}$ & $3.20-\mathrm{t}$ & $12.0 \mathrm{~h}$ & $6.0 \mathrm{k}-\mathrm{p}$ & 21.0de & $10.2 \mathrm{c}$ & $\mathrm{Ot}$ & $0 \mathrm{t}$ & $0 \mathrm{t}$ & $2.6 \mathrm{q}-\mathrm{t}$ & $0 \mathrm{t}$ & $0.5 \mathrm{~g}$ & $5.4 \mathrm{~cd}$ \\
\hline & $\mathrm{N}_{2} \mathrm{P}_{2} \mathrm{~K}_{2}$ & $6.0 \mathrm{k}-\mathrm{p}$ & $0 \mathrm{t}$ & $6.4 \mathrm{k}$ & $1.8 \mathrm{r}-\mathrm{t}$ & $18.0 \mathrm{ef}$ & $6.4 \mathrm{~d}$ & $0 \mathrm{t}$ & $11.0 \mathrm{~h}$ & $15.0 \mathrm{~g}$ & $0 \mathrm{t}$ & 3.6n-r & $5.9 \mathrm{~d}$ & $6.2 \mathrm{c}$ \\
\hline $\mathrm{x}$ & & $7.5 \mathrm{fgh}$ & 1.61-o & $9.2 \mathrm{f}$ & $3.9 \mathrm{i}-1$ & $19.5 \mathrm{~d}$ & $8.3 \mathrm{~b}$ & $0 \mathrm{o}$ & 5.5hij & $7.5 \mathrm{fgh}$ & 1.3 no & $1.81-\mathrm{o}$ & $3.2 \mathrm{~d}$ & $5.8 \mathrm{~b}$ \\
\hline \multirow{2}{*}{ Ślęza } & $\mathrm{N}_{1} \mathrm{P}_{1} \mathrm{~K}_{1}$ & $36.0 \mathrm{~b}$ & $26.0 \mathrm{c}$ & $25.0 \mathrm{c}$ & $22.0 \mathrm{~d}$ & $21.0 \mathrm{de}$ & $26.0 \mathrm{~b}$ & $0 \mathrm{t}$ & $3.0 \mathrm{p}-\mathrm{t}$ & $2.6 \mathrm{q}-\mathrm{t}$ & $3.0 \mathrm{p}-\mathrm{t}$ & $0 \mathrm{t}$ & $1.7 \mathrm{~g}$ & $13.9 \mathrm{~b}$ \\
\hline & $\mathrm{N}_{2} \mathrm{P}_{2} \mathrm{~K}_{2}$ & $41.0 \mathrm{a}$ & $43.0 \mathrm{a}$ & $20.0 \mathrm{de}$ & $26.0 \mathrm{c}$ & $26.0 \mathrm{c}$ & $31.2 \mathrm{a}$ & 4.61-r & $2.2 \mathrm{q}-\mathrm{t}$ & $2.4 \mathrm{q}-\mathrm{t}$ & $5.41-\mathrm{q}$ & $0 \mathrm{t}$ & $2.9 \mathrm{ef}$ & $17.1 \mathrm{a}$ \\
\hline $\mathrm{x}$ & & $38.5 \mathrm{a}$ & $34.5 \mathrm{~b}$ & $22.5 \mathrm{c}$ & $24.3 \mathrm{c}$ & $23.2 \mathrm{c}$ & $28.6 \mathrm{a}$ & $2.3 \mathrm{k}-\mathrm{n}$ & $2.6 \mathrm{k}-\mathrm{n}$ & $2.5 \mathrm{k}-\mathrm{n}$ & $4.2 \mathrm{ijk}$ & $0 \mathrm{o}$ & $2.3 \mathrm{e}$ & $15.5 \mathrm{a}$ \\
\hline
\end{tabular}

Explanations as in Table 2

Table 5

Infection of potato tubers by Streptomyces scabies (infection index Ii in \%)

\begin{tabular}{|c|c|c|c|c|c|c|c|c|c|c|c|c|c|c|}
\hline \multirow{3}{*}{ Cultivar } & \multirow{3}{*}{ NPK } & \multicolumn{6}{|c|}{2009} & \multicolumn{6}{|c|}{2010} & \multirow{3}{*}{$X$} \\
\hline & & \multicolumn{5}{|c|}{ Foliar fertilization } & & \multicolumn{5}{|c|}{ Foliar fertilization } & \multirow{2}{*}{$\mathrm{X}$} & \\
\hline & & A & B & $\mathrm{C}$ & $\mathrm{G}$ & $\mathrm{H}$ & $\boldsymbol{\lambda}$ & A & $\mathrm{B}$ & $\mathrm{C}$ & G & $\mathrm{H}$ & & \\
\hline \multirow{2}{*}{ Adam } & $\mathrm{N}_{1} \mathrm{P}_{1} \mathrm{~K}_{1}$ & $4.0 \mathrm{j}-\mathrm{m}$ & $1.3 \mathrm{opq}$ & $4.7 \mathrm{jk}$ & 2.71-p & $4.1 \mathrm{jkl}$ & $3.4 \mathrm{~g}$ & $3.2 \mathrm{j}-\mathrm{o}$ & $4.8 \mathrm{jk}$ & $3.2 \mathrm{j}-\mathrm{o}$ & $4.9 \mathrm{jk}$ & $4.8 \mathrm{jk}$ & $4.2 \mathrm{f}$ & $3.8 \mathrm{c}$ \\
\hline & $\mathrm{N}_{2} \mathrm{P}_{2} \mathrm{~K}_{2}$ & $3.3 \mathrm{j}-\mathrm{n}$ & $1.3 \mathrm{opq}$ & $0 \mathrm{q}$ & $1.3 \mathrm{opq}$ & $1.3 \mathrm{opq}$ & $1.4 \mathrm{i}$ & $22.2 \mathrm{~b}$ & $3.3 \mathrm{k}-\mathrm{o}$ & $13.3 \mathrm{e}$ & $10.0 \mathrm{f}$ & $3.3 \mathrm{j}-\mathrm{n}$ & $10.4 \mathrm{~b}$ & $5.9 \mathrm{~b}$ \\
\hline $\mathrm{x}$ & & 3.7ghi & $1.3 \mathrm{mno}$ & $2.4 \mathrm{j}-\mathrm{m}$ & $2.0 \mathrm{k}-\mathrm{n}$ & $2.7 \mathrm{i}-1$ & $2.4 \mathrm{~d}$ & $12.7 \mathrm{c}$ & 4.9ghi & $8.3 \mathrm{e}$ & $7.5 \mathrm{e}$ & 4.1gh & $7.3 \mathrm{c}$ & $4.8 \mathrm{~b}$ \\
\hline \multirow{2}{*}{ Pasja Pomorska } & $\mathrm{N}_{1} \mathrm{P}_{1} \mathrm{~K}_{1}$ & $12.2 \mathrm{e}$ & $12.7 \mathrm{e}$ & $12.4 \mathrm{e}$ & $18.9 \mathrm{c}$ & $25.3 \mathrm{a}$ & $16.3 \mathrm{a}$ & 2.51-p & $2.41-p$ & $0 \mathrm{q}$ & $4.2 \mathrm{jkl}$ & $3.3 \mathrm{j}-\mathrm{n}$ & $2.5 \mathrm{~h}$ & $9.4 \mathrm{a}$ \\
\hline & $\mathrm{N}_{2} \mathrm{P}_{2} \mathrm{~K}_{2}$ & $4.0 \mathrm{j}-\mathrm{m}$ & $4.7 \mathrm{jk}$ & $10.0 \mathrm{f}$ & $3.3 \mathrm{j}-\mathrm{n}$ & $10.2 \mathrm{f}$ & $6.4 \mathrm{e}$ & 1.6n-q & $0 \mathrm{q}$ & $1.6 n-q$ & 2.41-o & $0 \mathrm{q}$ & $1.1 \mathrm{i}$ & $3.8 \mathrm{~b}$ \\
\hline $\mathrm{x}$ & & $8.1 \mathrm{e}$ & $8.7 \mathrm{e}$ & $11.2 \mathrm{~d}$ & $11.1 \mathrm{~d}$ & $17.8 \mathrm{a}$ & $11.4 \mathrm{a}$ & $2.1 \mathrm{j}-\mathrm{n}$ & $1.21-\mathrm{o}$ & $0.8 \mathrm{no}$ & 3.3hij & $1.71-\mathrm{o}$ & $1.8 \mathrm{e}$ & $6.6 \mathrm{a}$ \\
\hline \multirow{2}{*}{ Ślęza } & $\mathrm{N}_{1} \mathrm{P}_{1} \mathrm{~K}_{1}$ & $4.7 \mathrm{jk}$ & $13.6 \mathrm{e}$ & $7.6 \mathrm{gh}$ & $8.7 \mathrm{fg}$ & $12.2 \mathrm{e}$ & $9.4 \mathrm{c}$ & $0 \mathrm{q}$ & $0 \mathrm{q}$ & 2.41-p & $0.8 \mathrm{pq}$ & $5.1 \mathrm{ij}$ & $1.7 \mathrm{i}$ & $5.5 \mathrm{~b}$ \\
\hline & $\mathrm{N}_{2} \mathrm{P}_{2} \mathrm{~K}_{2}$ & $6.7 \mathrm{hi}$ & $15.3 \mathrm{~d}$ & $2.2 \mathrm{~m}-\mathrm{p}$ & $7.1 \mathrm{gh}$ & $5.1 \mathrm{ij}$ & $7.3 \mathrm{~d}$ & $0.8 \mathrm{pq}$ & $1.7 \mathrm{n}-\mathrm{q}$ & $1.4 n-q$ & $0 \mathrm{q}$ & $0.8 \mathrm{pq}$ & $0.9 \mathrm{i}$ & $4.1 \mathrm{c}$ \\
\hline $\mathrm{x}$ & & $5.7 \mathrm{f}$ & $14.5 \mathrm{~b}$ & $4.8 \mathrm{fg}$ & $7.9 \mathrm{e}$ & $8.7 \mathrm{e}$ & $8.3 \mathrm{~b}$ & $0.4 \mathrm{o}$ & 0.9 no & $1.9 \mathrm{k}-\mathrm{n}$ & $0.4 \mathrm{o}$ & 3.0h-k & $4.8 \mathrm{~b}$ & \\
\hline
\end{tabular}

Explanations as in Table 2

Table 6

Infection of potato tubers by Rhizoctonia solani (infection index Ii in \%)

\begin{tabular}{|c|c|c|c|c|c|c|c|c|c|c|c|c|c|c|}
\hline \multirow{3}{*}{ Cultivar } & \multirow{3}{*}{ NPK } & \multicolumn{6}{|c|}{2009} & \multicolumn{6}{|c|}{2010} & \multirow{3}{*}{$\mathrm{X}$} \\
\hline & & \multicolumn{5}{|c|}{ Foliar fertilization } & & \multicolumn{5}{|c|}{ Foliar fertilization } & \multirow{2}{*}{$\mathrm{x}$} & \\
\hline & & A & B & $\mathrm{C}$ & G & $\mathrm{H}$ & & A & B & $\mathrm{C}$ & G & $\mathrm{H}$ & & \\
\hline \multirow{2}{*}{ Adam } & $\mathrm{N}_{1} \mathrm{P}_{1} \mathrm{~K}_{1}$ & $15.1 \mathrm{c}-\mathrm{f}$ & $15.8 \mathrm{~b}-\mathrm{e}$ & $18.7 \mathrm{bc}$ & $17.5 \mathrm{bcd}$ & 9.1ghi & $15.2 b$ & $7.9 \mathrm{~h}-\mathrm{k}$ & $9.5 \mathrm{ghi}$ & $10.3 \mathrm{gh}$ & $5.7 \mathrm{i}-\mathrm{o}$ & $11.9 \mathrm{fg}$ & $9.1 \mathrm{c}$ & $12.2 \mathrm{~b}$ \\
\hline & $\mathrm{N}_{2} \mathrm{P}_{2} \mathrm{~K}_{2}$ & 14.9def & $18.9 \mathrm{~b}$ & $26.2 \mathrm{a}$ & $17.1 \mathrm{bcd}$ & $27.1 \mathrm{a}$ & $20.8 \mathrm{a}$ & $12.3 \mathrm{efg}$ & $5.0 \mathrm{j}-\mathrm{p}$ & $3.3 \mathrm{~m}-\mathrm{q}$ & 5.7i-o & $3.3 n-q$ & $5.9 \mathrm{~d}$ & $13.4 \mathrm{a}$ \\
\hline $\mathrm{x}$ & & $15.0 \mathrm{c}$ & $17.4 \mathrm{bc}$ & $22.5 \mathrm{a}$ & $17.3 \mathrm{bc}$ & $18.1 \mathrm{~b}$ & $18.0 \mathrm{a}$ & $10.1 \mathrm{~d}$ & $7.3 \mathrm{e}$ & $6.8 \mathrm{ef}$ & 5.7efg & $7.6 \mathrm{e}$ & $7.5 b$ & $12.8 \mathrm{a}$ \\
\hline \multirow{2}{*}{$\begin{array}{l}\text { Pasja } \\
\text { Pomorska }\end{array}$} & $\mathrm{N}_{1} \mathrm{P}_{1} \mathrm{~K}_{1}$ & $1.5 \mathrm{qr}$ & $6.2 \mathrm{i}-\mathrm{n}$ & $6.7 \mathrm{~h}-\mathrm{m}$ & $1.1 q r$ & $1.3 \mathrm{qr}$ & $3.4 \mathrm{e}$ & $4.2 \mathrm{k}-\mathrm{q}$ & $3.3 n-q$ & Or & $0.8 \mathrm{r}$ & $4.1 \mathrm{k}-\mathrm{q}$ & $2.5 \mathrm{ef}$ & $2.9 \mathrm{c}$ \\
\hline & $\mathrm{N}_{2} \mathrm{P}_{2} \mathrm{~K}_{2}$ & $2.7 n-q$ & Or & $1.3 \mathrm{qr}$ & Or & $8.9 \mathrm{~g}-\mathrm{j}$ & 2.6ef & Or & Or & $2.4 \mathrm{o}-\mathrm{q}$ & $3.2 n-q$ & $2.20-\mathrm{q}$ & $1.6 \mathrm{f}$ & $2.1 \mathrm{c}$ \\
\hline $\mathrm{x}$ & & 2.1hij & $3.1 \mathrm{~g}-\mathrm{j}$ & 4.0ghi & $0.6 \mathrm{j}$ & 5.1efg & $3.0 \mathrm{~cd}$ & 2.1hij & 1.7hij & $1.2 \mathrm{ij}$ & 2.0hij & $3.2 \mathrm{~g}-\mathrm{j}$ & 2.0de & $2.5 \mathrm{~b}$ \\
\hline \multirow{2}{*}{ Ślęza } & $\mathrm{N}_{1} \mathrm{P}_{1} \mathrm{~K}_{1}$ & 2.0pqr & Or & $3.3 \mathrm{~m}-\mathrm{q}$ & $6.2 \mathrm{i}-\mathrm{n}$ & $6.7 n-m$ & $3.6 \mathrm{e}$ & Or & $1.7 \mathrm{r}$ & $0.7 \mathrm{r}$ & $0.8 \mathrm{r}$ & $2.4 \mathrm{o}-\mathrm{q}$ & $1.1 \mathrm{f}$ & $2.4 \mathrm{c}$ \\
\hline & $\mathrm{N}_{2} \mathrm{P}_{2} \mathrm{~K}_{2}$ & $2.7 n-q$ & $3.1 \mathrm{n}-\mathrm{q}$ & $3.1 n-q$ & $2.7 n-q$ & 7.3h-1 & $3.8 \mathrm{e}$ & $1.7 \mathrm{pqr}$ & $0.8 \mathrm{r}$ & $0.8 \mathrm{r}$ & 1.6pqr & $0.8 \mathrm{r}$ & $1.1 \mathrm{f}$ & $2.5 \mathrm{c}$ \\
\hline $\mathrm{x}$ & & 2.4hij & 1.6ij & $3.2 \mathrm{~g}-\mathrm{j}$ & $4.5 \mathrm{fgh}$ & 7.0ef & $3.7 \mathrm{c}$ & $0.9 \mathrm{j}$ & $1.3 \mathrm{ij}$ & $0.8 \mathrm{j}$ & $1.2 \mathrm{ij}$ & 1.6ij & $1.1 \mathrm{e}$ & $2.4 \mathrm{~b}$ \\
\hline
\end{tabular}

Explanations as in Table 2 


\section{CONCLUSIONS}

The highest percentage of potato tubers showing the symptoms of soft rot and late blight was observed in the wet growing season of 2010. In 2009 the highest severity of common scab and dry rot was noted on the tubers of the late cultivars, while the incidence of black scurf was highest on the tubers of the medium-early cultivar. After harvest, the severity of tuber diseases varied between treatments with two levels of mineral fertilization and foliar fertilization. Pathogens had a high (over 55\%) share in the fungal community colonizing stored tubers of all cultivars after storage and newly-harvested tubers of cv. 'Pasja Pomorska'. After harvest, the lowest number of pathogens was isolated from the tubers of cv. 'Adam' in the non-fertilized treatment, and after storage - from the tubers of the late cultivars in the treatment where three foliar fertilizers were applied in combination.

\section{Acknowledgements}

The study was supported financially by the Ministry of Science and Higher Education in 2008 - 2011 (research grant No. N N310 307334)

\section{REFERENCES}

Andrivon D., Lucas J.M., Guerin C., Jouan B., 1998. Colonization of roots, stolons, tubers and stems of various (Solanum tuberosum) cultivars by the blackdot fungus Colletotrichum coccodes.Plant Pathol. 47: 440-445.

Arxvon J.A., 1970. The genera of fungi sporulating in pure culture. Verlag von J. Cramer.

Bain R.A., Millard P., Perombelon M.C.M., 1996. The resistance of potato plants to Erwinia carotovora subsp. atroseptica in relation to their calcium and magnesium content. Potato Res. 39: 185-193.

Basu A., Hossain M.M., Konar A., Chettri M., 2003. Integrated management of late blight disease of potato. Ann. Plant Protect. Sci. 11 (1): 64-66.

Blachiński D., Shteiberg D., Dinoor A., Kafkafi U., Sujkowski LS., Zitter T.A., 1996. Influence of foliar application of nitrogen and potassium on Alternaria diseases potato, tomato and cotton. Phytoparasitica, 4: 281-292.

B olig łow a E., 2003. Wpływ dolistnego dokarmiania ziemniaka (roztworem mocznika i nawozami wieloskładnikowymi) na plon, jego strukturę, zdrowotność i trwałość przechowalniczą bulw. / Effect of foliar fertilizers on potato yield, its structure, wholesomeness and storage life of tubers. Acta Agrophys. 85: 99-106. (in Polish)

Brar M.S., Navdeep-Kaur., 2006. Effect of soil and foliar applied potassium and nitrogen on yield of potato (Solanum tuberosum) in alluvial soils of Punjab, India. Ind. J. Agricult. Sci. 76 (12): 740-743.

Celetti M J., Johnston H.W., Platt H.W., 1990.
A note on the incidence of soilborne fungi in six crops used in rotation with potatoes. Phytoprotection, 71: 97-100.

Cooke L.R., Little G., 2002. The effect of foliar application of phosphonate formulations on the susceptibility of potato tubers to late blight. Pest Manag. Sci. 58 (1): 17-25.

Cwalina-Ambroziak B., 2002. Grzyby zasiedlające bulwy ziemniaka (Solanum tuberosum L.) bezpośrednio po zbiorze i po przechowywaniu. / Fungi colonizing potato tubers (Solanum tuberosum L.) after harvest and after storage. Acta Agrobot. 56 (2): 133-140. (in Polish)

Domsch K.H., Gams W., Anderson TrauteHeidi, 1980. Compendium of Soil Fungi. Academic Press, A Subsidiary of Harcourt Brace Jovanovich Publishers, London, New York, Toronto, Sydney, San Francisco, 859.

E11 is M.B., 1971. Dematiaceus hyphomycetes. Commonwealth Mycological Institute Kew Surrey, England.

Esfahani M.N., 2006. Present status of Fusarium dry rot of potato tubers in Isfahan (Iran). Ind. Phytopath. 59 (2): 142-147.

Feng W., Zheng X., 2006. Control of Alternaria alternata by cassia oil combination with potassium chloride or sodium chloride. J. App. Microbiol. 101 (6): 1317 1322 .

Jabłoński K., 2003. Wpływ dolistnego nawożenia ziemniaka nawozami dolistnymi ADOB na plon roślin i jego strukturę oraz porażenie bulw chorobami./ Influence of ADOB foliar fertilization to potato leaves on the yield structure and tuber infestation with pathogens. Acta Agrophys. 85: 137-143. (in Polish)

Johnson D.A., Inglis D.A., Miller J.S., 2004. Control of potato tuber rots caused by oomcyetes with foliar applications of phosphorous acid. Plant Dis. 88:1153-1159.

Klikocka H., Haneklaus S. Schnug E., 2005. Influence of sulfur fertilization on infection of potato tubers with Rhizoctonia solani and Streptomyces scabies. J. Plant Nutrition, 28 (5): 819-833.

Kozera W., Nowak K., Majcherczak E., Barc z a k B ., 2006. Effect of foliar fertilization with microelements on the content of macroelements in potato tubers. J. Elementol. 11 (1): 29-34.

Kurzawińska H., 1997. Fungi occurring in potato tubers with dry rot symptoms. Phytopathol. Pol. 13: 79-84.

Loiveke H., 2006. Incidence of Fusarium spp. on several field crops in Estonia and their toxicity towards Bacillus stearothermophilus. Agronomy Res. 4 (Special Issue): 273-280.

Lutomirska B., Szutkowska M., 2005. Influence of the soil type and date of irrigation on tuber infection with Rhizoctonia solani Kühn). Progr. Plant Protec./ Post. Ochr. Roślin, 45 (2): 865-868. (in Polish)

Mamta J.M.M., Kumar S., 2005. Influence of organic manure, irrigation interval and cropping sequence on the field and black scurf disease of potato. Ann. Agri. 
Bio. Res. 10 (1): 61-64.

Mahmoud S.M., 2007. Management of brown rot disease of potato. Arab. Univ. J. Agricult. Sci. 15 (2): 457-463.

Mectau M.R., Arul J., Tweddell R.J., 2002. Effect of organic and inorganic salts on the growth and development of Fusarium sambucinum, a causal agent of potato dry rot. Mycol. Res. 106 (6): 688-696.

Mills A.A.S., Platt H.W., Hurta R.A.R., 2006. Sensitivity of Erwinia spp. to salt compounds in vitro and their effect on the development on soft rot in potato tubers in storage. Postharv. Biol. Tech. 41 (2): 208-214.

Osowski J., 2005. Możliwość wykorzystania cynku w ochronie ziemniaka przed alternariozą. Biul. IHAR 237/238: 187-193. (in Polish)

Peters J.C., Lees A.K., Cullen D.W., Sullivan L., Stroud G.P., Cunnington A.C., 2008. Characterization of Fusarium spp. responsible for causing dry rot of potato in Great Britain. Plant Pathol. 57: 262-271.

Pua J., Abza T., 2005. Healthiness of potato tubers after harvesting depending on fertilization./ Progr. Plant Protec./Post. Ochr. Roślin, 45 (2): 1019-1021. (in Polish)

Repsiene R., Mineikiene E.V., 2006. The influence of meteorological conditions and different agricultural systems on the spreading of potato $\mathrm{cv}$. 'Mirta' tuber diseases and their yield. Zemes ukio Mokslai. 2006 (3): 16-25.

Rę bar z K., B orów c z a k F., 2007. Porażenie patogenami bulw ziemniaków odmiany Bila w zależności od deszczowania, technologii uprawy i nawożenia azotowego. / Pathogen infestation of potato tubers of 'Bila' cultivar depending on irrigation, cultivation technology and nitrogen fertilization. Prog. Plant Protection/Post. Ochr. Roślin, 47: 294-298. (in Polish)

Ritchie F., Mc Quilken M., Bain R., 2006. Effects of water potential on mycelial growth, sclerotial production, and germination of Rhizoctonia solani from potato. Mycolog. Res. 110 (6): 725-733.

Roztropowicz S ., 1999. Metodyka obserwacji, pomiarów i pobierania próbek $w$ agrotechnicznych doświadczeniach z ziemniakiem. IHAR, Oddział Jadwisin: 37-38. (in Polish)

Trehan S.P., Sharma K.K., Grewal J.S., 1995. Effect of soil and foliar application of micronutrients and fungicides on late blight (Phytophthora infestans) and tuber yield of potato (Solanum tuberosum). Indian J. Agricult. Sci. 65 (11): 836-841.

\section{Patogeny występujące na bulwach ziemniaka (Solanum tuberosum L.) nawożonego dolistnie}

\section{Streszczenie}

W trzyletnim ścisłym doświadczeniu poletkowym założonym w 2008 r. w Bałcynach uprawiano odmiany ziemniaka: średnio wczesną 'Adam', średnio późną 'Pasja Pomorska' i późną 'Ślęza'. Czynnikami doświadczenia były: nawozy dolistne, stosowane pojedynczo i łącznie (Basfoliar 12-4-6, ADOB Mn, Solubor DF) oraz dwa poziomy nawożenia mineralnego doglebowego $\left(\mathrm{N}_{1} \mathrm{P}_{1} \mathrm{~K}_{1}-80 \mathrm{~kg} \mathrm{~N} \times \mathrm{ha}^{-1}, 80 \mathrm{~kg} \mathrm{P} \times \mathrm{ha}^{-1}\right.$, $120 \mathrm{~K} \times \mathrm{ha}^{-1} ; \mathrm{N}_{2} \mathrm{P}_{2} \mathrm{~K}_{2}-120 \mathrm{~kg} \mathrm{~N} \times \mathrm{ha}^{-1}, 144 \mathrm{~kg}$ $\mathrm{P} \times \mathrm{ha}^{-1}, 156 \mathrm{~K} \times \mathrm{ha}^{-1}$ ). Materiał badawczy stanowiły bulwy ziemniaka. Procent bulw z objawami mokrej zgnilizny (Pectobacterium carotovorum subsp. carotovorum), zarazy ziemniaka (Phytophthora infestans) i suchej zgnilizny (Fusarium spp.) szacowano w $5 \mathrm{~kg}$ próbie bulw. Po zbiorze w losowo pobranej próbie 100 bulw oceniano nasilenie parcha zwykłego (Streptomyces scabies) i ospowatości (Rhizoctonia solani); wynik podano jako indeks porażenia $\mathrm{w} \%$. W laboratorium co roku izolowano grzyby na pożywce PDA z bulw po zbiorze i po 5-miesięcznym przechowywaniu. Wyniki opracowano statystycznie (STATISTICA ${ }^{\circledR} 9.0$ 2009). Odmiany ziemniaka miały wpływ na nasilenie chorób bulw. Nasilenie analizowanych chorób na bulwach badanych po zbiorze pochodzących z roślin nawożonych doglebowo NPK i dokarmianych dolistnie nawozami wieloskładnikowymi było zróżnicowane. Zaobserwowano jednak prawidłowość: najmniej bulw porażonych przez Fusarium uzyskano u roślin dokarmianych trzema nawozami łącznie, co potwierdza najmniejsza liczebność izolatów tych grzybów otrzymanych z bulw. Więcej grzybów otrzymano z bulw po zbiorze niż po przechowywaniu, jednak patogeny częściej izolowano z bulw przechowywanych. Najrzadziej sprawców chorób wyosobniano $\mathrm{z}$ bulw nienawożonych roślin odmiany 'Adam' w analizowanym terminie po zbiorze i z bulw odmian późnych w kombinacji z łącznie aplikowanymi trzema nawozami, w analizowanym terminie po przechowywaniu. 
